\title{
A PARLIAMENTARY SATIRE OF 1675
}

\author{
By J. MILTON FRENCH
}

THE LIBRARY has recently acquired a collection of miscellaneous seventeenthcentury English verse in manuscript. The individual pieces range from a few lines of epigram to extended poems of one or two hundred lines, from Latin and Greek to English, and from literature through politics to sheer mud-slinging. In the following essay Dr. French has concerned himself with one example of the third category.

" CHARGE to the Grand Inquest of England" is an unsigned poem of about 140 lines of rhymed couplets attacking the English Parliament, or more specifically the House of
Commons. It is written in an ordinary secretary hand on three pages of paper measuring about $7 \frac{1 / 2}{2}$ by $1 \mathrm{I} 1 / 2$ inches. The fourth page is blank except for addresses. In writing so confused and apoplectic as sometimes to be virtually unintelligible the writer accuses the House of Commons of being composed of the off-scourings of England and of conspiring to effect the destruction of all that is good in the country.

In a style resembling that of many other political attacks of the time the writer begins by presenting an imaginary and satirical picture of the formal assembling of the rogues and villains who constitute the newly chosen Parliament. As we shall see later, the date is probably about 1674 or 1675 . The members are ushered in with the following stinging welcome: ${ }^{1}$

Room for the Bedlam Commons: hell and fury!

Room for the gentlemen of our Grand Jury,

Led by no conjuring bailiff with white wand,

But stately mace in stalking giant's hand.

Call them o'er, Crier, swear 'em every man,

And let an oath fetter 'em if it can.

The foreman first preferred before the rest

'Cause he has learnt the art of parting best [better]

${ }^{1}$ Spelling and punctuation are here modernized throughout. 
Than Howard, Powell, Garraway, and Meeres,

Temple and Marvell (who yet wears his ears),

Candish the Fox, Whorwood that senior soph ${ }^{2}$

Some fresh come on, some lately taken off.

Thereafter the writer pillories the "sacrilege, thefts, robberies and rapes, murders, cheats, perjuries" and similar pleasant performances in which these gentlemen of the House have recently indulged. In ironic advice to the law-makers to make sure of their own ill-gotten rights and privileges the writer encourages them to

Ransack your writers, Milton, Needham, Prynne;

Rather than fail, bring the sly Jesuit in.

Then (swol'n with pride and poison sucked from these)

Vote your own privilege is what you please.

This reference to Milton, which to the best of my knowledge has not previously been noted, arises of course from his stout adherence to the Parliament in the time of the Civil War. He is coupled with Marchamont Needham because they were associated in the production of the pro-Commonwealth journal Mercurius Politicus, and with William Prynne because, though never working together, both fought against the encroachments of the monarchy. It may be remembered that whereas earlier the writer gnashes his teeth over the fact that the poet Andrew Marvell had never had his ears trimmed off as he deserved to for his villainy in supporting the Parliament, Prynne lost his twice in the days before the defeat and death of King Charles I. The association here is not one which would have pleased Milton.

The wicked lawgivers are also accused of trying to distract attention from their own vices by the red herrings of sallies against

$$
\begin{aligned}
& \text { Popery, } \\
& \text { Power arbitrary, the prerogative regal, } \\
& \text { Monopolies, imprisonments illegal, } \\
& \text { Offices set to sale, }
\end{aligned}
$$

and other vices which, however deserving of punishment, are attacked by these vicious legislators with false motives. They do not hesitate to cut off the political heads of those whom they fear:

\footnotetext{
2 I.e., sophister or sophomore, a student in his second or third year at Oxford or Cambridge.
} 


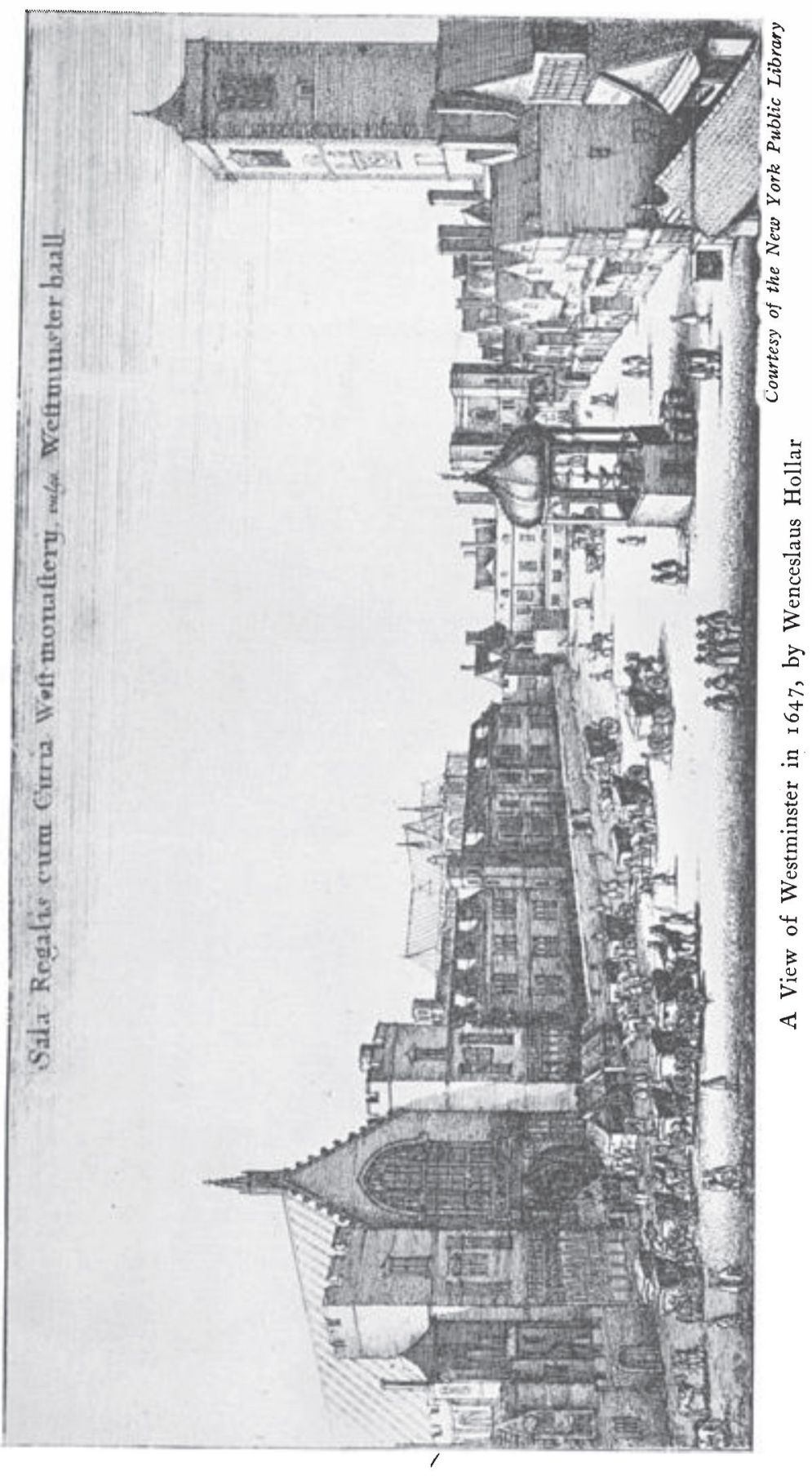


Impeachment on impeachment next renew,

With impudent address against all who

Have better heads or truer hearts than you.

What is worse, the Commons even sacrifice the safety of their country when they find a chance to line their pockets. When Belgium and Holland attacked England and seemed likely to defeat the country, Parliament refused to rally to the defence.

When the proud Belgic Lion stood at bay

In pride of Greece,

At once the easier and the nobler prey ...

When such a friend by chance kind Fortune threw,

No more expected than deserved by you,

Who but a Parliament could slight it? When

We might have drown'd that lion in his den,

Or beat him to a fawning whelp again,

Kindly you spar'd your money and your foe.

Eventually the country will pay heavily for this venality.

The tirade ends with derision rather than with fury. After all, these Parliamentarians are not so much criminal, the writer implies, as simply sly and stupid; not so much tigers as skunks. So he sends them home to their fit reward, ignominy rather than punishment.

Thus when your power, though not your pride, abates,

Your purses grown as empty as your pates,

'Tis time to send you home to your estates,

Where your wives (that they might be understood

T' have been more active for the public good

In their low sphere than you), to crown the plot,

Present you little babes you ne'er begot.

A note written at the top of the first sheet and another note at the end offer an interesting if brief biography of the poem.

The first note, written above the title and opening lines of the poem, is as follows:

\section{Honoured Sir:}

November 22, 1675 .

Here is no news in Town, only the Parliament is ready to go together by the ears. This is the first lampoon [to] have been made since my 
master came to Town. What else comes out, Your Worship shall receive from

Your most dutiful and obedient servant,

John Seaman.

From this note we may assume that in the fall of I 675 this satire was fresh and timely and that it was in circulation in London.

The address of the recipient appears on the fourth page, together with faint remnants of the seal with which the missive was fastened. It was addressed as follows: "These for the Honourable Sir William Godbold at Mr. Thomas Baxter's house in Mendham, Suffolk." Another address, also on the fourth page, reads: "These for Mr. Thomas Baxter at Mendham." But this second address almost certainly accompanies a note which has been written on the third page at the end of the poem. The second note reads:

When I came, Cousin, from yours, I found this in my coat pockets, which I here return. And as for William Godbold's title, he brought me a note out of the register book of Tunnington which clearly makes appear that one William Godbold was brother to Sir William's father by Ann his mother, so that his children are of the whole blood and heir at law to Sir William. I believe Mr. Bohun, who married his daughter, her children are th' only heir to Sir William. This he might have found before had he looked but five years after Sir William's father's birth. I thought it not an ill act to signify this to you, and hearty thanks is all from

Your assured to serve you

$$
\text { [signed] Jo. Cornwallis [seal] }
$$

Aug. I 7 th, 1687 .

The satire evidently, then, had done some traveling. First picked up in London in the fall of $\mathrm{I} 675$ by John Seaman, it was sent by him to Sir William Godbold at the home of his friend (and Seaman's master?) Thomas Baxter in Mendham, Suffolk. Some eleven years later John Cornwallis, a relative of Baxter, picked it up while visiting Baxter and absent-mindedly stuffed it into his pockets. Discovering it after arriving home, he sent it back with apologies, at the same time making use of it as a vehicle for sending a genealogical note about their families which they had probably just been discussing. 
It may possibly be worth while to carry this little investigation one step further and inquire who these people were and what their relation to each other was. From the point of view of the editor of the $D N B$ they were all nonentities except Mr. Bohun, who was probably Edmund Bohun (1645-1699), for a time licenser of publications in England and Chief Justice of Carolina. But the volume of pedigrees of Suffolk people printed in the publications of the Harleian Society at least partially identifies them.

Edmund Bohun the licenser and justice (if I identify him correctly) was the son of Edmund Bohun of Westhall, co. Suffolk, and Dorothy, daughter of Stephen Baxter of Mendham, co. Suffolk. Our Thomas Baxter, born in I638, was the son of a Stephen Baxter and the grandson of this Stephen Baxter of Mendham. Thus Thomas Baxter and Edmund Bohun the licenser, mentioned in John Cornwallis's letter, were first cousins, being the children of Dorothy (Baxter) Bohun and her brother Stephen Baxter. Edmund Bohun the licenser in turn married Mary, daughter of William Godbold. Godbold's earlier pedigree does not appear. But I believe we are justified in assuming that the Sir William Godbold to whom John Seaman sent the satire was a fairly close relative of the Thomas Baxter at whose house he lived, and that the Bohun mentioned in the second note was Baxter's cousin.

John Cornwallis's relation to them does not appear. He was of a Suffolk family with links to both Cretingham and Framsden. Just which member of the family he was is hard to tell. A John Cornwallis (frequently spelled Cornwaleys) of Cretingham was the second son of Sir Thomas Cornwallis ( 15 19-1604), Comptroller of the Household to Queen Elizabeth and James I. His son John married twice and had a son John; and one of these Johns signed the pedigree printed in the Harleian Society volume. We may guess that our John was the youngest. His relation to Sir William Cornwallis the essayist, if any, is distant. Similarly that of Thomas Baxter to the noted divine and author Richard Baxter is uncertain.

In summary we may say that, while it is by no means important, this little squirt of venom now resurrected from the past at least brings home to us that the trade of the column gossiper was practiced long before the I940's. It also proves that the foundations of free speech among English-speaking peoples have been long laid. 